\title{
Does the Lowest Bid Price Evaluation Criterion Make for a More Efficient Public Procurement Selection Criterion? (Case of the Czech Republic)
}

\author{
František Ochrana, Kristýna Hrnč́řrová ${ }^{1}$
}

\begin{abstract}
Through the institute of public procurement a considerable volume of financial resources is allocated. It is therefore in the interest of contracting entities to seek ways of how to achieve an efficient allocation of resources. Some public contractawarding entities, along with some public-administration authorities in the Czech Republic, believe that the use of a single evaluation criterion (the lowest bid price) results in a more efficient tender for a public contract. It was found that contracting entities in the Czech Republic strongly prefer to use the lowest bid price criterion. Within the examined sample, $86.5 \%$ of public procurements were evaluated this way. The analysis of the examined sample of public contracts proved that the choice of an evaluation criterion, even the preference of the lowest bid price criterion, does not have any obvious impact on the final cost of a public contract. The study concludes that it is inappropriate to prefer the criterion of the lowest bid price within the evaluation of public contracts that are characterised by their complexity (including public contracts for construction works and public service contracts). The findings of the Supreme Audit Office related to the inspection of public contracts indicate that when using the lowest bid price as an evaluation criterion, a public contract may indeed be tendered with the lowest bid price, but not necessarily the best offer in terms of supplied quality. It is therefore not appropriate to use the lowest bid price evaluation criterion to such an extent for the purpose of evaluating work and services. Any improvement to this situation requires a corresponding amendment to the Law on Public Contracts and mainly a radical change in the attitude of the Office for the Protection of Competition towards proposed changes, as indicated within the conclusions and recommendations proposed by this study.
\end{abstract}

1 Center for Social and Economic Studies, Faculty of Social Sciences, Charles University in Prague. 
Key words: Public procurement, criteria for evaluation of public contracts, estimated price of a public contract, final price of a public contract, impact of the lowest bid price criterion on the final price of a public contract, the lowest bid price, principle of economy.

\section{Introduction}

The institute of public procurement governs a significant reallocation of resources. In 2012, a total of $12.8 \%$ of GDP was spent on public contracts in the Czech Republic (MMR 2014). Within the direct regime of public procurement - i.e. the mandatory award of public contracts pursuant to Act No. 137/2006 Coll., On Public Contracts, as amended (hereinafter "Act on Public Contracts") - approximately $60 \%$ of the volume of outlaid financial resources is awarded within the public procurement market. The remaining $40 \%$ of expended funds are allocated through the institute of small-scale contracts (possibly on the basis of exemptions from the Act on Public Contracts). The dominant position among the procurers of public contracts stays with public procurers, who in terms of the volume of financial resources represent an $85 \%$-share of the public-procurement market. This level of financial resources represents $28 \%$ of the total volume of expenditures by the general government sector (CSO 2014; MMR 2014).

Obviously, this is a considerable amount of financial resources. It is therefore in the interest of public authorities to create an effective procurement management and to search for factors that increase the efficiency of public procurement. Do they also include the prioritisation of the lowest bid price evaluation criterion, as some contracting authorities in the Czech Republic believe? Finding the answer to this question represents the research objective of this study.

Acknowledgement: The study was undertaken within the framework of PRVOUK project P-17, entitled "The social, political and media sciences in the face of contemporary challenges" (Faculty of Social Sciences, Charles University Prague).

\section{Theoretical foundations}

In order to secure necessary goods and services, the public sector may either employ its own production or it may alternatively opt for the outsourcing way (Prager 1994; Mikušová Meričková and Nemec 2013). The contracting authority establishes the necessary legal procedures for this purpose (Jurčík 2007) and at the same time aims to get the required quality of the necessary product/service for the lowest possible price. Towards this end, it may use either a single evaluation criterion (the lowest bid price) or it may evaluate the individual submitted bids based on multiple evaluation criteria. 
Using the example of eight Central European countries (Slovakia, Poland, Czech Republic, Austria, Hungary, Estonia, Latvia and Lithuania) and three Western European countries (UK, France and Germany) between the years 2009 and 2013 Nemec, Mikušová Meričková and Grega (2014) examine the role of the lowest bid price as an evaluation criterion in the public procurement of goods, services and public works. From their analysis it becomes clear that the Czech Republic, along with Slovakia and Poland, ranks among countries that significantly prefer the criterion of the lowest bid price within the evaluation of public procurement. This preference of the lowest bid price as an evaluation criterion in public procurement (ranging around $80 \%$ of all evaluated contracts) markedly contrasts with the abovementioned Western European countries which, by contrast, prefer a multi-criterial evaluation of public procurement.

The selection of evaluation criteria depends on the discretion of the contracting authority. In case the contracting authority opts for a single evaluation criterion (the lowest bid price), a prerequisite of its use is that the selection of an offer with the lowest bid price corresponds to the principle of economy, meaning that for the lowest incurred cost the given target of public procurement was indeed met. In case the contracting authority uses multiple criteria, the Act on Public Contracts requires that for each criterion its weight must be specified in percentage points. The bid price is one of the evaluation criteria.

Evaluation criteria represent the key instrument in selecting the best offer. It therefore makes sense to ask: what role in the procurement management does the selection of the evaluation criteria play? Does the choice of evaluation criteria have an impact on the final price of public procurement? Is the evaluation criterion of the lowest bid price the most appropriate yardstick for the selection of public procurement?

That is to say, some awarding entities in the Czech Republic are of the opinion (according to information obtained from a survey conducted by the authors of this study at a training seminar of awarding authorities over the period 2005-2013) that the criterion of the lowest bid price is the most appropriate measure for evaluating public contracts, since the use of the criterion of the lowest bid price reportedly leads to a lower final price compared to the use of a multi-criterial evaluation of public procurement. This view is based on the following argumentation: the contracting authority is obliged to disclose the estimated price of a public contract and the evaluation criteria. For tender participants the estimated price of a public contract represents an important piece of information for the formulation of their contest strategy. Provided the evaluation criterion is solely the lowest bid price, the candidate in turn takes into account only this information within the formation of its bidding strategy. It seeks to "squeeze" its bid price down as much as possible so 
that the offered price is at the margin of profitability with the expectation to win the public tender. $^{2}$

According to the reasoning of the above-mentioned contracting authorities, more factors enter into the strategic decision-making of applicats regarding their bid price in case the assessment of public procurement is undertaken on the basis of multiple criteria, such as the quality of their offering, technical parameters, deadlines or other properties specified by individual evaluation criteria. The applicant is thus not so intensely "pushed" to reduce its bid price down to the very threshold of public contract's profitability. Instead, the bidder may offer a slightly higher price compared to the single-criterial assessment of tender bids based on the lowest bid price.

The argumentation of the aforementioned contracting authorities seems logical in that the applicant may compensate its (slightly higher) bid price within multicriterial procurement evaluation (compared to the price that would have been offered under the evaluation of bids by the sole criterion of the lowest bid price) by, e.g., a higher quality of the offered product or by some other desired parameter included in the multi-criterial evaluation of tender bids. However, is this really the case? Are proponents of this view from the ranks of contracting authorities correct in assuming that the use of the lowest bid price criterion results in a lower final price when compared to the assessment of public procurement based on multiple criteria? The following empirical data analysis will attempt to answer this question. ${ }^{3}$

2 The tender applicant thus plays a "risky game" in that its aversion to risk significantly influences into what risky decisions it will enter with the bid price (with respect to other offers with the expected bid price). For more on the issue of risk aversion see Neumann and Morgenstern (1944) and Arrow (1971).

3 In the Czech Republic, there are several studies dealing with the empirical analysis of public procurement. For example, Pavel and Kubík (2011) point towards the impact that the number of tender participants has on the tendered price. Nikolovová et al. (2012) examined the role of the influence of the institutional environment and behaviour of awarding authorities on the effectiveness of public procurement. The collective work by Kameník et al. (2011) examines the openness of procurement procedures. The issue of the competitive environment in waste management and its impact on municipal expenditures is dealt with by Soukopová and Malý (2013). In the Slovak Republic, the empirical analysis of public procurement is particularly dealt with by Meričková et al. (2010), Nemec (2012), Sičáková Beblavá and Beblavý (2009), Vlček (2004) and Vozárová (2012). The OECD study (2003) and the study by the European Commission (see Strand et al. 2011), which focus on an openness of public tendering and public-procurement efficiency, contributed particularly to the analysis of public procurement in the EU member states. For now, what stands rather sideways is the examination of the impact of the evaluation criteria on the final price of public procurement and whether the choice of evaluation criteria is in any way related to the openness of public competition. One of the exceptions is, e.g., the work by Nemec et al. (2014), which establishes the issue of efficiency versus economy in public procurement. Our analysis builds upon this work with a focus on the Czech Republic. 


\section{Data and their empirical analysis}

Data on public contracts were obtained using a random selection from publicly available internet sites "Bulletin of public contracts" (www.vestnikverejnychzakazek.cz) and "Contracts Plus" (www.zakazky-plus.cz). In total there were 1,027 public contracts related to construction works that were published on the aforementioned internet portals within the period August-October 2013. The given sample of public contracts was adjusted for small-scale contracts (the portals included them in the below-the-threshold category of public contracts) and for public procurement for which the form "Notice of a contract award" did not include one of the following characteristics: the date the public contract was published on the procurement portal; the registration number of the public contract; the name, type and main activity of the contracting authority; the name and type of the construction-work contract; the type of the award procedure; evaluation criteria (including types and weights of sub-criteria for multi-criterially assessed contracts); the date when the contract was awarded; the number of bids; the initially estimated price; the final price; supplementary information on whether the contract is to be awarded within a simplified, below-the-threshold procedure. The adjustment resulted in a file of 557 below-the-threshold public contracts. A representation of individual contracting entities is shown in Table 1.

Table 1

Representation of contracting entities using single- and multi-criterially evaluated public-procurement procedures

\begin{tabular}{|l|c|c|}
\hline \multicolumn{1}{|c|}{ Type of procurer } & $\begin{array}{c}\text { Single-criterially } \\
\text { evaluated bids (\%) }\end{array}$ & $\begin{array}{c}\text { Multi-criterially } \\
\text { evaluated bids (\%) }\end{array}$ \\
\hline Regional or municipal authorities & 77 & 77 \\
\hline $\begin{array}{l}\text { Regional or municipal offices and } \\
\text { agencies }\end{array}$ & 14 & 9 \\
\hline Public institutions & 9 & 14 \\
\hline
\end{tabular}

Source: Examined sample. Own calculations.

As evident from Table 1, within the examined sample regional and municipal authorities clearly dominate; this is identical (77\%) for both single- and multi-criterially evaluated public procurement. In terms of the object matter, for which eleven major object areas of activity are distinguished, services to the public unequivocally dominate ( $85 \%$ share in single-criterially evaluated contracts and $78 \%$ share in multi-criterially assessed contracts). 


\subsection{Estimated and final price of single- and multi-criterially evaluated public contracts}

The Act on Public Contracts obliges public procurers to announce the estimated value of a contract within the published contract documentation. From an economic point of view, the estimated value of a public contract represents the value of collectively consumed goods/services (Meričková Mikušová and Stejskal 2014).

The question arises whether the final price is influenced by the choice of specific evaluation criteria. Is it possible to prove that opting for the selection criterion of the lowest tender bid price leads to a lower final price vis-à-vis multi-criterially evaluated public contracts? To answer this question we perform an analysis of the examined sample of public contracts. The examined sample demonstrates the following characteristics with respect to estimated and final prices (see Table 2).

\section{Table 2}

Examined sample of public procurements and comparison of estimated and final prices

\begin{tabular}{|l|r|r|r|r|}
\hline & \multicolumn{2}{|c|}{ Single-criterion contracts } & \multicolumn{2}{c|}{ Multi-criterion contracts } \\
\cline { 2 - 5 } & \multicolumn{1}{|c|}{$\begin{array}{c}\text { estimated } \\
\text { price }\end{array}$} & $\begin{array}{c}\text { final } \\
\text { price }\end{array}$ & $\begin{array}{c}\text { estimated } \\
\text { price }\end{array}$ & \multicolumn{1}{c|}{$\begin{array}{c}\text { final } \\
\text { price }\end{array}$} \\
\hline Minimum (in CZK) & $1,005,885$ & 919,090 & $1,410,853$ & 685,871 \\
\hline Maximum (in CZK) & $96,300,000$ & $87,999,000$ & $110,000,000$ & $106,524,806$ \\
\hline Average (in CZK) & $10,593,167$ & $8,010,740$ & $12,764,231$ & $10,312,615$ \\
\hline Median (in CZK) & $6,188,500$ & $4,752,161$ & $8,272,518$ & $5,999,620$ \\
\hline Total volume (in CZK) & $4,186,587,361$ & $3,861,176,642$ & $906,260,447$ & $773,446,182$ \\
\hline
\end{tabular}

Source: Examined sample of public procurements. Own analysis. EUR $1=$ CZK 27.

From the analysis of the examined sample and the comparison of estimated and final prices for single-criterially evaluated contracts it is clear that all values of the final price are lower compared to the estimated price. For public contracts evaluated on the basis of the lowest bid price the average final price of procurement approaches $75 \%$ of the estimated price. When comparing the estimated and final prices for multi-criterially evaluated public contracts, we see that there is also a difference between the estimated and final price similar to the case of single-criterially assessed bids. The average final price for multi-criterially evaluated public contracts approaches the level of approx. 81 per cent of the estimated price. The difference between the estimated and final price of public contracts evaluated on the basis of the 
lowest bid price evaluation criterion and procurements evaluated based on multiple criteria is not significant. ${ }^{4}$

The data in Table 2 point towards another interesting fact. That is, the final minimum price for both single- and multi-criterially evaluated contracts has fallen below CZK 1 million. This finding is surprising. At the time when we examined the sample (to be precise, as of 1 January 2014) the lower limit for awarding below-thethreshold public contracts stood at CZK 1 million for supplies and services and at CZK 3 million for construction works. We would expect that the final price would not likely "fall" below this threshold. However, as we can see from the data in Table 2 , in the case of multi-criterially evaluated contracts the minimum price has fallen down to a mere CZK 685,000. Similarly for single-criterially evaluated public procurements, the final price came down below the level of CZK 1 million. What was the cause of such a reduction in the final price, compared to the estimated value of public procurement?

Several possible explanations come forward. A relevant explanation suggests the aforementioned effect of a competitive environment, when the competitive environment in public procurement pushes toward lower final prices. Another cause of the identified incompatibility may lie in an inaccurate estimate on the part of the given contracting authority in determining the estimated value of a public contract. This conclusion is supported by findings from the conducted training of public procurers. It turns out that some procurers do not know methods of how to calculate (estimate) the expected price of a public contract. However, there are other possible complementary explanations that call to be checked within some further studies.

\subsection{Distribution of the number of single- and multi-criterially evaluated bids}

The analysis of the examined sample of public contracts confirms the conclusion at which Nemec et al. (2014) have arrived in their study on the dominance of singlecriterially evaluated public contracts over public procurement evaluated based on multiple criteria. In our examined sample, single-criterially evaluated public contracts were represented by an $86.5 \%$ share of the total number of surveyed public contracts. Contracts evaluated based on multiple criteria constituted only $13.5 \%$ of the total number of public contracts. Let us ask how the number of single- and multi-criterially evaluated bids differs.

The distribution of the number of bids submitted for single-criterially evaluated public contracts and for public contracts evaluated based on multiple criteria is shown in Diagram 1.

4 In case there are differences between the estimated and final prices, they result from other factors. The most important one is an openness of public competition and the interrelated competitive environment, as shown, e.g., by Iimi (2006), Pavel and Sičáková Beblavá (2008) and as we also demonstrate within the next section of this study. 


\section{Diagram 1}

Distribution of the number of bids for single-criterially evaluated public contracts

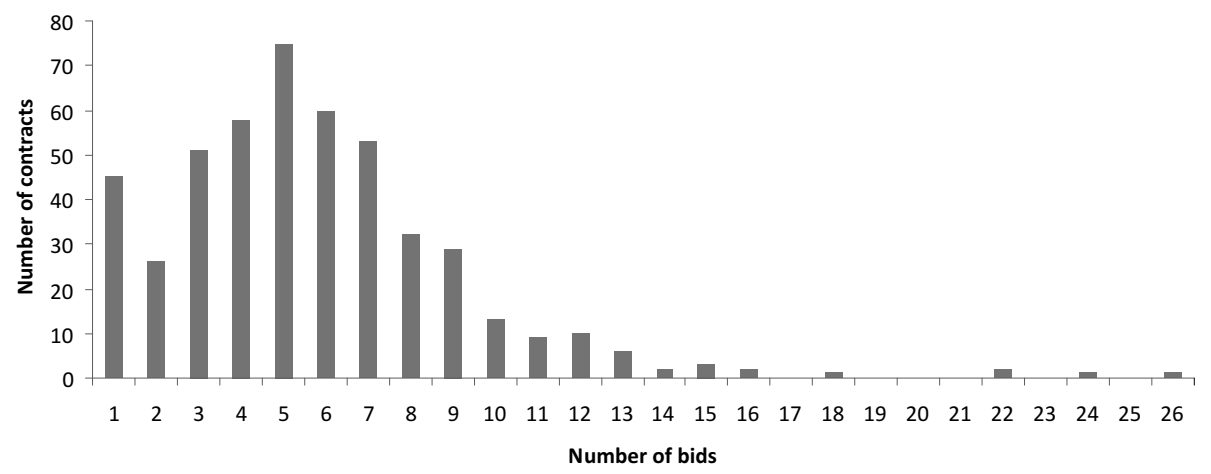

Source: Examined sample. Own calculations.

From the above diagram it is clear that the number of single-criterially evaluated bids ranges for the examined sample within the interval from one to twentysix bids. The highest frequency is from one to seven bids, followed by a gradual decrease in the higher number of bids.

A similar situation is also characteristic of the distribution in the number of bids evaluated based on multiple criteria (see Diagram 2).

\section{Diagram 2}

Distribution of the number of bids for multi-criterially evaluated public contracts

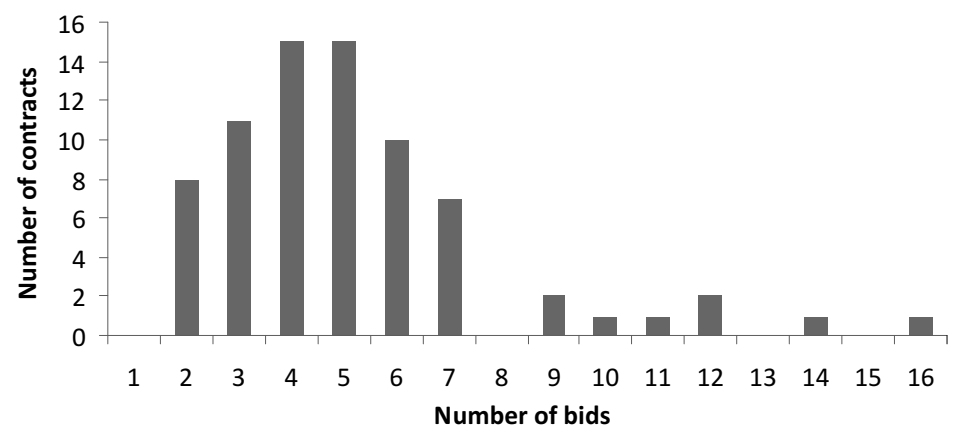

Source: Examined sample. Own calculations.

Also in the case of multi-criterially evaluated bids, the largest frequency is up to seven submitted offers. Compared to single-criterially evaluated public procure- 
ment, however, this number of seven bids is apparently backed by a lower frequency in bids.

Let us also note that when compared to single-criterially evaluated public contracts, multi-criterially evaluated bids have a lower span of the number of bids, ranging from one to sixteen offers. This may probably be explained by the fact that multi-criterially evaluated bids are adopted for financially more substantial contracts and for procurement objects characterised by a higher degree of complexity (objects of public procurement with more complex structures). It can therefore be assumed that for such public contracts, the necessary implementation capacity is possessed by only a smaller number of potential candidates. The result is a lower distribution of the number of bids for multi-criterially evaluated public contracts. This presumption may be corroborated by the finding (see Table 2) that the average estimated price for single-criterially evaluated public contracts is lower than the average estimated price for multi-criterially assessed public procurement. Also the median of the final and estimated price for single- and multi-criterially evaluated public contracts points towards a similar difference in prices.

\subsection{Number of single- and multi-criterially evaluated bids within individual types of procurement procedures}

In this part of the study, will try to answer the question whether the number of bids in individual types of procurement procedures differs for the cases related to single-criterially and multi-criterially evaluated bids. We will examine the given issue within the context of the competitive effect.

We start with the assumption that a higher number of bids creates a more competitive environment while the number of bids depends on the type (openness) of the procurement procedure. The following types of award procedures were investigated: open procedure, restricted procedure, negotiated procedure with publication, negotiated procedure without publication and simplified below-the-threshold procedure. First, we shall examine single-criterially evaluated bids. The number of bids in each type of procurement procedure is shown in Table 3 (next page).

As evident from the table, the largest share of all types of procurement procedures (measured by the share on the total number of single-criterially evaluated public contracts) has an open procedure. 40 per cent of the examined sample of single-criterially evaluated public contracts were tendered using an open procurement procedure. This type of procurement procedure may be considered the most open type of tender procedure. The distribution of the number of tender bids for this type of procurement procedure is shown in Diagram 3 below. 


\section{Table 3}

Number and share of bids in individual types of procurement procedures (single-criterially evaluated bids)

\begin{tabular}{|l|c|c|c|c|c|}
\hline & $\begin{array}{c}\text { Open } \\
\text { procedure }\end{array}$ & $\begin{array}{c}\text { Restricted } \\
\text { procedure }\end{array}$ & $\begin{array}{c}\text { Negotiated } \\
\text { procedure } \\
\text { with } \\
\text { publication }\end{array}$ & $\begin{array}{c}\text { Negotiated } \\
\text { procedure } \\
\text { without } \\
\text { publication }\end{array}$ & $\begin{array}{c}\text { Simplified } \\
\text { below-the- } \\
\text { threshold } \\
\text { procedure }\end{array}$ \\
\hline $\begin{array}{l}\text { Share of the } \\
\text { given procedure } \\
\text { on the total } \\
\text { number of } \\
\text { contracts (\%) }\end{array}$ & 40.0 & 3.4 & 8.9 & 10.4 & 37.3 \\
\hline $\begin{array}{l}\text { Average number } \\
\text { of bids }\end{array}$ & 6.67 & 7 & 6.26 & 1.71 & 5.72 \\
\hline $\begin{array}{l}\text { Median (number } \\
\text { of bids) }\end{array}$ & 6 & & 4 & 1 & 5 \\
\hline
\end{tabular}

Source: Examined sample. Own calculations.

\section{Diagram 3}

Distribution of the number of tender bids for single-criterially evaluated public contracts (open procedure)

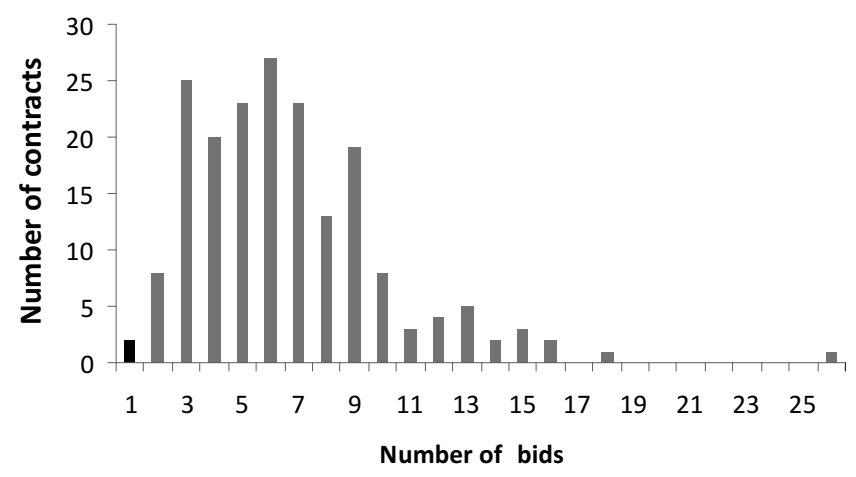

Source: Examined sample. Own calculations.

As evident from the examined sample, even for the given sample it holds true that single-criterially evaluated public contracts demonstrate a relatively high competitive environment in an open procurement procedure. This is confirmed by the average representation of 6.67 bids in an open procurement procedure.

Although the open procedure potentially reaches all candidates, there are cases when the competition enters only a single bid, as also shown in our analysis. Causes may differ. One example is the fact that other competitors eventually withdraw from the tender. 
The relatively high number of average bids also recorded other types of procurement procedures - restricted procedures and negotiated procedures with publication, which may also be ranked among open types of procurement procedures.

Negotiated procedures without publication rank among public-procurement procedures with a relatively small degree of openness. Their case is depicted in Diagram 4 below.

\section{Diagram 4}

Distribution of the number of bids for single-criterially evaluated public contracts (negotiated procedure without publication)

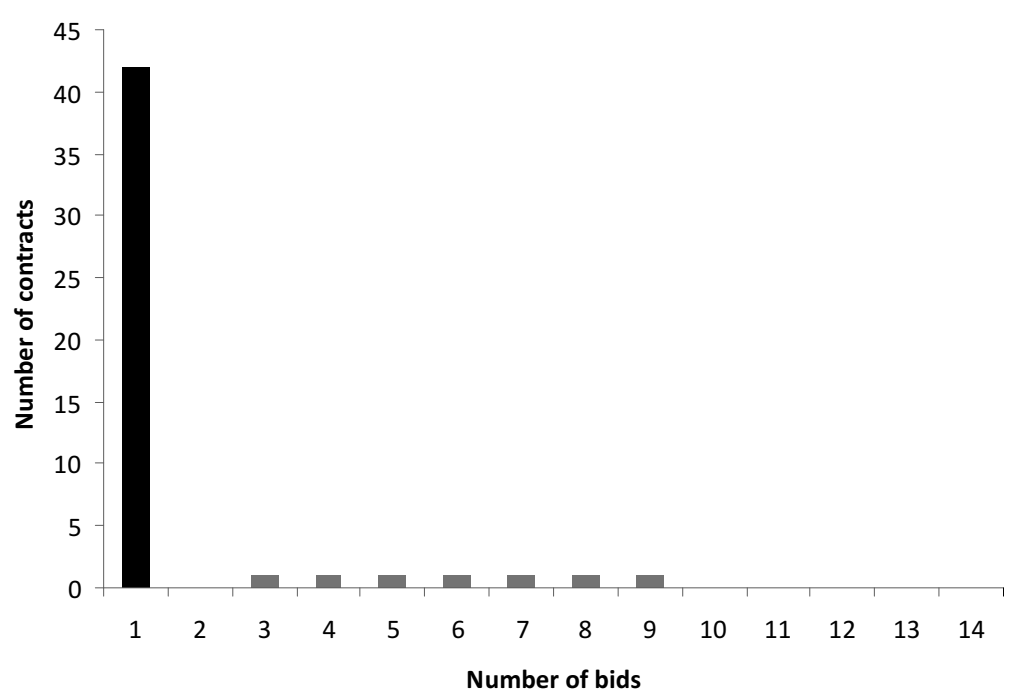

Source: Examined sample. Own calculations.

As obvious from the analysis of this type of tender procedure, most contracts are tendered with only one offer. This significantly reduces the competitiveness of the public tender. It is a consequence of the fact that within this type of procurement procedure, only one or two candidates are being addressed, which obviously restricts the competitiveness in public procurement. Such a case, when only a single bid is being tendered, may be labelled a "bad practice" of procurement management.

The simplified below-the-threshold procedure represents a special case. For this type of procurement procedure, the contracting authority is mandated to reach a minimum of five candidates. In Diagram 5 this dissimilarity is expressed using a colour-differentiation of the appropriate column, representing the number of bids. 


\section{Diagram 5}

Distribution of the number of bids for single-criterially evaluated public contracts (simplified below-the-threshold procedure)

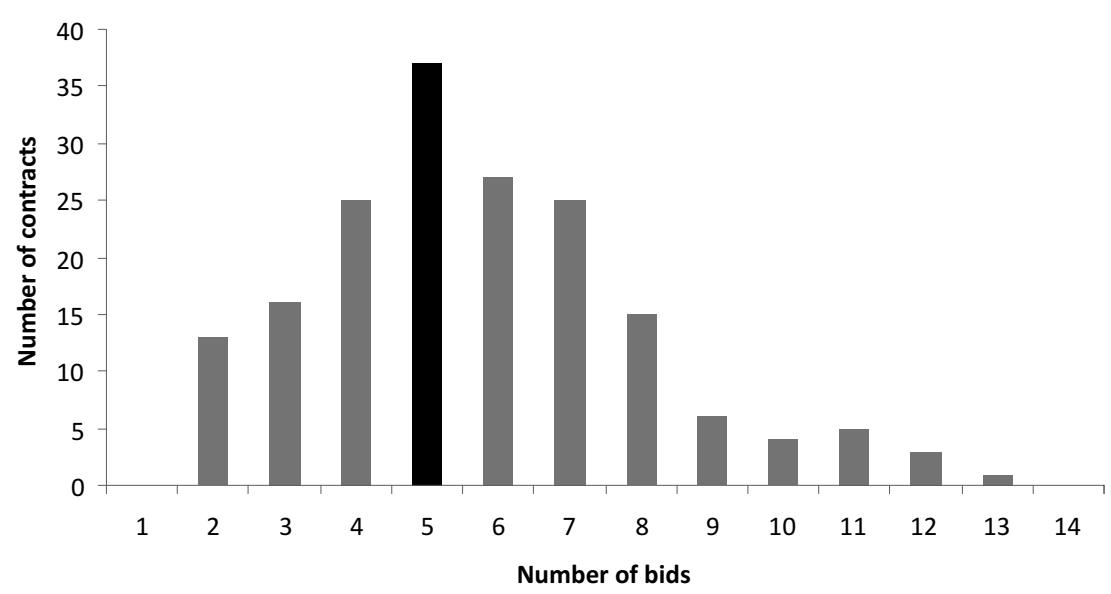

Source: Examined sample. Own calculations.

The average number of bids is 5.72. In this type of award procedure, the contracting authority is obligated to reach five bidders for a public contract. The analysis, however, shows that in some cases the number of bids is less than the mandated minimum of five offers. This is due to the fact that while the contracting authority addresses at least five candidates, it happens that the contracting entity does not receive respective bids from all the candidates it has invited.

Now we examine the distribution of the number of offers that are evaluated based on multiple criteria. Results of the analysis are shown in Diagram 6 below. 


\section{Diagram 6}

Distribution of the number of bids for multi-criterially evaluated public contracts (open procedure)

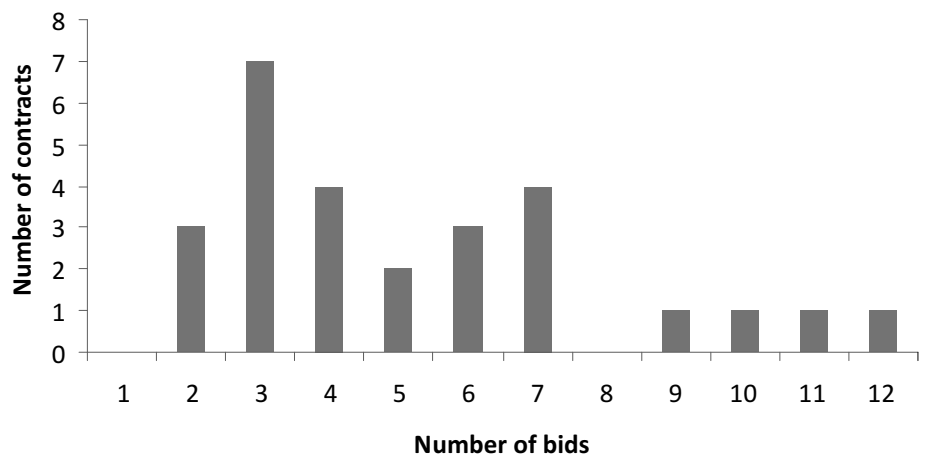

Source: Examined sample. Own calculations.

As apparent from the distribution of bids, the examined sample of public contracts also demonstrates a fairly wide range in the number of bids (from 2 to 12 offers). Therefore, we may conclude that this is a fairly competitive environment.

In the case of a simplified below-the-threshold procurement procedure (see Diagram 7 below), where the contracting authority addresses five contenders for a public contract, there also appears a similar phenomenon that we encounter for single-criterially evaluated public contracts. As the chart shows, using a simplified below-the-threshold procurement procedure, in the case of multi-criterially evaluated public contracts most frequently four offers are made. This can be explained by the fact that some invited candidates did not submit their bids.

\section{Diagram 7}

Distribution of the number of bids for multi-criterially evaluated public contracts (simplified below-the-threshold procurement procedure

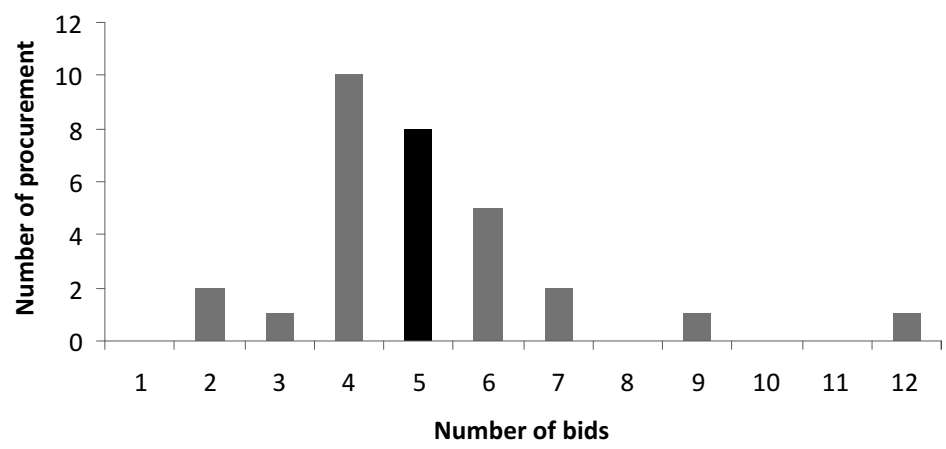

Source: Examined sample. Own calculations. 
From examining a number of bids in each type of procurement procedure, when public contracts were evaluated either on the basis of the single evaluation criterion of the lowest bid price or based on several evaluation criteria, it may be concluded that the average number of bids in each type of contracting procedure does not significantly differ between the single- and multi-criterially evaluated contracts. For example, the difference in the average number of tender bids in an open and restricted procedure is about 0.5 bids. It is therefore possible to conclude that the choice of a particular type of criterion does not have any significant effect on the number of submitted bids. This means that the single evaluation criterion of the lowest bid price does not significantly affect the competitive environment. Therefore, the perceived myth on the part of the public contractors who claim a significant impact of the lowest bid price criterion on the final price of public procurement does not hold true. We will try to explore this conclusion in more detail within the following analysis.

\subsection{Economic implications on the final price using single- and multi- criterion evaluation}

To evaluate the competitive environment and explore the impact of the choice of evaluation criteria on the final price, we will adopt a standardised difference in prices, as defined by Nikolovová et al. (2012). This relationship may be expressed as follows:

$\mathrm{NR}=(\mathrm{FP}-\mathrm{EP}) / \mathrm{EP}$, where

$\mathrm{NR}$ is a normalised difference in prices;

FP is the final price;

EP is the estimated price.

For the given relationship it holds that if the normalised price difference is negative, the final price is less than the estimated price. In this case we can conclude that a public contract was awarded in a competitive environment. The procuring authority has been able to save funds (Půček and Ochrana 2014). Provided the price difference is positive, the final price is higher than the estimated price. In this case we may assume that the effect of competition is missing. If the normalised price difference is zero it means that the final and estimated prices are equal.

The analysis of the examined sample of public contracts shows that public contracts evaluated on the basis of a single factor have a variance of the normalised difference in prices in the range from -1 to +0.5 . For multi-criterially evaluated contracts there a narrower range from -0.55 to +0.2 was determined. In both cases, the majority of contracts recorded a lower final price compared to the original estimate.

The analysis of the average difference in normalised prices that assists the assessment of the impact that different types of procurement procedures have on the final price of public procurement may be supplemented by a regression analysis 
(method of ordinary least squares, OLS). The results of this analysis are shown in Tables 4 and 5 . The normalised price differential is treated as an explained variable while individual types of procurement procedures are used as explanatory variables.

Table 4

Dependence of a normalised price on the type of procedure (single-criterial contracts)

\begin{tabular}{|c|c|c|c|c|}
\hline Endogenous variable & \multicolumn{4}{|c|}{ normalised price } \\
\hline Exogenous variable & \multicolumn{4}{|c|}{ individual types of procedures } \\
\hline \multirow[t]{2}{*}{$\begin{array}{l}\text { Number of } \\
\text { observations }\end{array}$} & \multicolumn{4}{|l|}{397} \\
\hline & Coefficient & Std. error & t-statistics & Probability \\
\hline Constant & -0.03866 & 0.027316 & -1.415248 & 0.1578 \\
\hline Open procedure & -0.25076 & 0.031042 & -8.078226 & 0.0000 \\
\hline Restricted procedure & -0.23116 & 0.057199 & -4.041321 & 0.0001 \\
\hline $\begin{array}{l}\text { Procedure with } \\
\text { publication }\end{array}$ & -0.17623 & 0.040417 & -4.360316 & 0.0000 \\
\hline Simplified procedure & -0.19738 & 0.031019 & -6.363307 & 0.0000 \\
\hline $\begin{array}{l}\text { Coefficient of } \\
\text { determination }\end{array}$ & 0.144483 & & & \\
\hline $\begin{array}{l}\text { Adjusted coefficient } \\
\text { of determination }\end{array}$ & 0.135754 & & & \\
\hline F-test (probability) & 0.000000 & & & \\
\hline
\end{tabular}

Source: Examined sample. Own calculations.

All considered variables are significant at the $1 \%$ level of significance. As apparent from the analysis, open procedures demonstrate a relatively high degree of competitive environment. A negative correlation between open procedures and the price differential is apparent. This may be interpreted in the way that as the number of bids increases, the final price drops. However, with respect to the performed analysis it is necessary to critically note that the coefficient of determination is clearly low.

In the case of public contracts evaluated based on multiple criteria, it was rather complicated to put together an appropriate model. The number of bids in each type of procurement procedure (except for an open procedure) was low. Therefore, it was necessary to exclude all other types of award procedures, including constants. This left us only with an open procedure, which is significant at the $1 \%$ level of significance. The research results are shown in Table 5. 


\section{Table 5}

Dependence of a normalised price on the type of procedure (multiple-criterial contracts)

\begin{tabular}{|c|c|c|c|c|}
\hline Endogenous variable & \multicolumn{4}{|c|}{ normalised price } \\
\hline Exogenous variable & \multicolumn{4}{|c|}{ individual types of procedures } \\
\hline \multirow[t]{2}{*}{ Number of observations } & \multicolumn{4}{|l|}{71} \\
\hline & Coefficient & Std. error & t-statistics & Probability \\
\hline Open procedure & -0.258930 & 0.046106 & -5.616035 & 0.0000 \\
\hline Coefficient of determination & -0.548966 & & & \\
\hline $\begin{array}{l}\text { Adjusted coefficient of } \\
\text { determination }\end{array}$ & -0.548966 & & & \\
\hline
\end{tabular}

Source: Examined sample. Own calculations.

As evident from the results of the analysis, the relationship between an open procedure and the price differential shows a negative correlation. Any decrease in the tendered price therefore depends on the growth in the number of tender bids. In this case the coefficient of determination is significantly higher than for singlecriterially evaluated contracts. The model can explain approximately one half of all cases considered. However, it needs to be critically noted that the sample of multicriterially evaluated contracts was relatively small. For other examined procurement types, however, we have failed to demonstrate any significant effect on the final price. This can be explained by the small number of observations for other types of procurement procedures.

\section{Conclusions}

The analysis of public procurement in the Czech Republic leads to the conclusion that the number of bids and the final price are independent of the choice of evaluation criteria. Regardless, contracting authorities overwhelmingly prefer the lowest price as an award criterion in public procurement, when in approximately fourfifths of the cases they prefer the use of this evaluation criterion. Contracting authorities justify this practice using the following arguments:

The first argument is a supposed larger effect of the lowest bid price on the final cost of public procurement due to the formation of a more competitive environment. Empirical analysis, however, does not support this "myth of contracting authorities" regarding the more efficient impact of the lowest bid price evaluation criterion towards the reduction in the final price of a public contract.

Also the next assumption of contracting authorities, that through favouring the criterion of the lowest bid price it is possible to achieve savings for the public 
sector in that it is a less complex evaluation procedure, has proven to be unfounded. Compared to the total cost of procurement, transaction costs associated with procurement procedures are negligible. ${ }^{5}$ Conversely, an inappropriate use of the lowest bid price criterion for procurement of goods and services leads to a waste of resources. This fact is also pointed out by the latest findings of the Supreme Audit Office of the Czech Republic from June 2014, when, e.g., during repair works carried out on the busiest Czech motorway D1 (the motorway between Prague and Brno) a number of faults were identified. In this case, the offer with the lowest bid price, but with a very low (unsatisfactory) quality of the performed work, was selected. The same case we also register in construction works on other highway communications and in many instances of public contracts for services. From an economic perspective it is the case of non-compliance with the principle of economy within the adoption of the lowest bid price criterion. While tendering an offer with the lowest bid price, this offer subsequently does not meet the expected aim of the public contract. A conflict arises between efficiency and economy in public procurement.

We see a possible remedy in an amendment to the Act on Public Contracts and in a change to the behaviour of the Office for the Protection of Competition. We recommend that the contracting authorities be required to adhere not only to the principles of non-discriminatory, fair and transparent procedures, but also to comply with the principles of economy, efficiency and effectiveness in public procurement. These principles are still missing in the current amendment to the Act on Public Contracts (effective since 1 January 2014).

We also recommend to task the contracting authority with the duty to set its objectives and indicators within the tender documentation of public contracts, on the basis of which it would be possible to make an effective selection of the best offer. It is desirable that the Act on Public Contracts expressly stipulate the obligation on the part of the contracting authority that as long as it adopts the lowest bid price criterion, this criterion shall be used in accordance with the principle of economy. Therefore, there should not be instances where the award is made to the most favourably priced bid, if it is of a very low (or even unsatisfactory) quality. ${ }^{6}$ This bad practice calls for a change.

\section{References}

Arrow, K. 1971. Essays on the Theory of Risk-Bearing. Amsterdam-London: NorthHolland.

5 Pavel (2014) states they make up "approx. $1.6 \%$ of the contract price, while the median value is much lower - only $0.4 \%$."

6 For a similar case of an issue with the quality of public services under the conditions of Slovakia, see Nemec et al. (2013). 
CSO. 2014. Czech Statistical Office. Available at http://www.czso.cz (last accessed February 15, 2015).

Iimi, A. 2006. "Auction Reforms for Effective Official Development Assistance." Review of Industrial Organization 28(2), 109-128.

Jurčík, R. 2007. "The Economic Impact of the EC Procurement Policy." Agricultural Economics-Zemedelska ekonomika 7, 333-337.

Kameník, M. (ed.), P. Nikolovová, J. Palguta, F. Pertold, J. Soudek, M. Vozár, K. Andrlová and P. Prchal. 2011. Otevřenost zadávacích řizenív ČR. Praha: Oživení, o.s.

Meričková, B., J. Nemec, E. Sičáková Beblavá and M. Beblavý. 2010. Kontrahovanie služieb vo verejnom sektore. Bratislava: Transparency International Slovensko.

Meričková Mikušová, B. and J. Stejskal. 2014. "Hodnota statku kolektivní spotřeby." Politická ekonomie 62(2), 216-231.

Mikušová Meričková, B., Nemec, J. 2013. "Contract Management and its Impact on contracting Public Services: Slovak Republic.” Ekonomický časopis, 61(7), 690-699.

MMR. 2014. Výroční zpráva o stavu veřejných zakázek v České republice za rok 2013 [Annual report on the state of public procurement in the Czech Republic in 2013]. Prague: Ministry of Regional Development.

Nemec, J. 2012. "Zmluvné zabezpečovanie verejných služieb." Ekonomický časopis $50(6), 9-11$.

Nemec, J., B. Mikušová Meričková and M. Grega. 2014. "Contracting, Outsourcing, Procurement: Selected Factors Limiting their Success in the CEE Region." $18^{\text {th }}$ IRSPM Conference, 9-11 April, Carleton University. Ottawa, Canada. Available at http://www.irspm2014.com/index.php/irspm2014/IRSPM2014/ paper/view/211 (last accessed October 15, 2014).

Nemec, J., B. Mikušová Meričková and Z. Vozárová. 2013. "Management of Contracting Public Services and its Quality in Slovakia." NISPAcee Journal of Public Administration and Policy 5(1), 55-74.

Neumann, J. von and O. Morgernstern. 1944. Theory of Games and Economic Behavior. Princeton: Princeton University Press.

Nikolovová, P., J. Palguta, F. Pertold and M. Vozár. 2012. Veřejné zakázky v ČR. Co řikají data o chování zadavatelu?? Praha: Národohospodářský ústav AV ČR.

OECD. 2003. Transparency in Government Procurement: The Benefit of Efficient Governance and Orientations for Achieving It. Paris: OECD. 
Pavel, J. 2014. "Factors Affecting the Value of Compliance Costs of Public Procurement." $19^{\text {th }}$ international expert conference "Theoretical and Practical Aspects of Public Finance", Vysoká škola ekonomická v Praze, 11-12 April 2014. In Sedmihradská, L. (ed.) Proceedings of the $19^{\text {th }}$ International Conference Theoretical and Practical Aspects of Public Finance 2014. Prague: Wolters Kluwer, 222-227.

Pavel, J. and R. Kubík. 2011. "Faktory ovlivňující intenzitu konkurenčního efektu při zadávání veřejných zakázek na stavební práce v ČR.” In Kubátová, K. (ed.). Theoretical and Practical Aspects of Public Finance. Praha: Oeconomia, 3-10.

Pavel, J. and E. Sičáková Beblavá. 2008. “Transparentnost trhu verejného obstarávania." Ekonomický časopis 56(2), 168-181.

Prager, J. 1994. "Contracting out Government Services. Lessons from the Private Sector." Public Administration Review 54, 176-184.

Půček, M. and F. Ochrana. 2014. "Theory and Practice of the Public Sector Savings: The Case of Czech Regions." Transylvanian Review of Administrative Sciences 42E, 203-224.

Sičáková Beblavá, E. and M. Beblavý. 2009. "Rozhodovanie slovenských miest o postupoch obstarávania verejných služieb.” Ekonomický časopis 57(7), 667-681.

Soukopová, J. and I. Malý. 2013. "Competitive Evironment in Waste Management and its Impact on Municipal Expenditures." Acta Universitatis Agriculturae et Silviculturae Mendelianae Brunensis, 61(4), 173-183.

Strand, I., P. Ramada, E. Canton et al. 2011. Public Procurement in Europe. Cost and Effectiveness (Prepared for the European Commission, March 2011). London: $\mathrm{PwC}$, London Economics and Ecorys.

Vlček P. 2004. "K problematike hodnotenia efektívnosti zabezpečovania verejných služieb na báze syntetického ukazovatela." Ekonomika a spoločnost' 5(1), $74-81$.

Vozárová, Z. 2012. Kontrahovanie služeb vo veřejném sektore. [Contracting of Services in the Public Sector]. Dissertation thesis. Univerzita Mateja Bela v Banském Bystrici. Economic Faculty. 